\title{
Treatment Wetlands as Ecotechnological Tools for Regenerative Reclamation of Wastewater: Experiences from Working with Kalyani Model
}

\author{
Jayanta K. Biswas and Sukanta Rana
}

\begin{abstract}
Presently world is facing mounting water stress, both in quantity and quality, which has prompted many municipalities for a more efficient use of the water resources, including a widespread acceptance of water reuse practices. Treatment technology encompasses a vast variety of options. As a low-cost, eco-friendly approach constructed wetlands are recently promoted for wastewater treatment and end use applications of reclaimed water. The present study was conducted to assess the performance of a series of treatment wetlands (waste stabilization ponds) in wastewater purification in Kalyani, West Bengal, India in the perspective of reclamation and bioregenerative reuse of reclaimed wastewater. The waste stabilization ponds have been proved very efficient and cost-effective nature-based system for increasing the ecological value of wastewater in culturing aqua-crops and thus converting organic wastes into fish biomass.
\end{abstract}

Index Terms-Heterotrophic bacteria, fish, nitrogen, phosphorus, regenerative reclamation, treatment wetlands, wastewater.

\section{INTRODUCTION}

Wastewater generates from point and diffused municipal and industrial sources and contains a vast array of chemical substances-a cocktail of both helpful and harmful ones. Continuous discharge of wastewater from diverse anthropogenic activities into the natural system is creating material imbalance and adversely affecting the aquatic ecology. Typical municipal sewage treatment plant requires high capital investment, technical expertise and is energy-intensive. In developing countries, such treatment plants are not considered as an economically viable option. Treatment should not also let the nutrient-enriched wastewater down the drains and nutrients and water should be reused in productive use by closing the nutrient loop [1]. Treatment wetland systems exemplify systems of low-cost, low-tech, low maintenance and minimal energy demanding system and therefore, can be promoted as appropriate eco-based solutions to wastewater problem. Recently there has been a major shift in reclamation strategies from costly conventional technology to low-cost, eco-friendly, sustainable eco-technology using living machines, hypolimnetic aeration, and treatment wetlands. Biological wastewater treatment includes all methods that involve organisms, and emulate at least some of the natural ecosystem processes. Several biological treatment systems emulate decomposer communities wherein degradation

Manuscript received April 14, 2013; revised July 2, 2013.

The authors are with International Centre for Ecological Engineering, University of Kalyani, Kalyani, Nadia 741235, India (e-mail biswajoy2000@yahoo.com, sukanta_rana@ rediffmail.com).
Jayanta K. Biswas and Sukanta Rana processes predominate (treatment with activated sludge) and others emulate productive ecosystems where assimilation is important (wastewater-fed aquaculture). A World Bank report [2] strongly advocated for waste stabilization ponds as low-cost, effective and sustainable systems to be used for wastewater treatment and reuse in agriculture. Another important way of utilizing wastewater in economic activities is aquaculture where income of essential elements such as nitrogen, phosphorous, organic carbon from sewage can be converted into biomass resource. Wastewater-fed aquaculture, therefore, offers means to treat wastewater with integrated material-flow recycling. West Bengal is the pioneering state in India where such age-old, innovative and effective practices are underway involving many sewage-fed fish farms. Kalyani is a modern town of West Bengal established in 1945 with a well-planned underground sewerage system. A sewage treatment plant was constructed in 1993 under Ganga Action Plan (GAP) receiving $17 \times 10^{6} 1 \mathrm{~d}^{-1}$ of domestic wastewater from about 82000 inhabitants of the township. Of the total amount of sewage generated per day, about $11 \times 10^{6} 1$ is treated through conventional treatment plant, whereas the remaining $6 \times 10^{6} 1$ enters into a series of stabilization ponds before being discharged into the river Ganga.

Wetlands improve water quality by acting as sediment sinks, filters and sponges for nutrients and toxicants. They are rightly regarded as 'nature's kidneys' or 'nature's liver' owing to their filtering and clean-up functions. Removal of pollutants relies on a combination of physical, chemical and biological processes naturally occurring in wetlands and are associated with vegetation, sediments and their microbial communities. As biologically active ecosystems bolstered with many active bio-filters wetlands transform many pollutants at a high rate and have increasingly been used for wastewater treatment [3].

Considered as complex bioreactors in natural setting wetlands' ability to transform and trap organic matter and nutrients has been harnessed in constructed wetlands. Such wetlands are appropriate, low-cost, ecologically-based solutions, particularly for treating and reusing municipal sewage in developing regions. The central aim of the system is wastewater purification and nutrient assimilation into biomass. These artificial treatment systems consist of shallow ponds planted with aquatic plants. Being the man-made mimics of natural wetlands they optimally exploit the biogeochemical cycles and have evolved into a reliable treatment technology for wastewater reclamation and remediation [4]. The reduction of ubiquitous parameters like BOD, COD, total suspended solids and nutrients, pathogens, 
heavy metals and trace organic contaminants has been the focus of recent research [5]. Several hydrophytes in treatment wetlands have been proved effective in accumulation, removal, detoxification and/or immobilization of heavy metals [6]. Studies have shown that wastewater-fed aquaculture involving a series of $2-3$ ponds has significant sanitization properties by reducing load of coliforms, faecal coliforms, Salmonella sp. and faecal streptococci to acceptable levels [7].

As biological reactors treatment wetlands can be used as ecotechnogical tools for improving water quality. Despite great wastewater treatment efficacy and spin off values, this ecotechnology has not been applied as widely as it deserves. Ecotech approach toward sewage treatment using constructed wetlands seeks a symbiotic mix of man-made and ecological self-design that maximizes system efficiency including economic and environmental system. Allowing self-organization and minimizing human manipulation and management, materials cycling and recycling is achieved with enhanced efficiency but at reduced costs utilizing nature's living library and technology. Thus an ecotech issue is the design and operation of interface "buffer" ecosystems to handle byproducts of the human economy, like wastewater [8]. The ecotechnology applied in the Kalyani model of treatment wetlands for wastewater reclamation is designed to achieve multi-stage treatment: first-stage organic load reduction by anaerobic ponds; second-stage of biological treatment by facultative ponds and third-stage maturation pond driven tertiary treatment for further removal of pathogens. Wastewater aquaculture has been included within this eco-friendly plan of sewage treatment as it provides an extra output of fish with high-protein content. The present study was undertaken in sewage treatment pond series employed in the Kalyani model from April 2007 to March 2008 to assess the potential of treatment wetlands for removal of pollutants and bioregenerative reclamation of nutrients.

\section{MATERIALS AND METHODS}

\section{A. Experimental Ponds}

The sewage treatment ponds employed in the present study fall under three different categories: two anaerobic $(26 \mathrm{~m} \times$ $52 \mathrm{~m} \times 2.5 \mathrm{~m})$, two facultative $(64 \mathrm{~m} \times 150 \mathrm{~m} \times 1.5 \mathrm{~m})$ and four maturation ponds $(52 \mathrm{~m} \times 156 \mathrm{~m} \times 1 \mathrm{~m})$. All ponds were arranged in succession. Ponds of different categories are connected with the successive ones; maturation ponds are serially connected finally connected to a canal falling into the river Ganga. The sewage water covered a distance of $826 \mathrm{~m}$ from inlet to the final outlet of the sewage treatment farm maintaining respective average retention time of 1.13 days in anaerobic ponds, 4.8 days in facultative ponds and 5.41 days in the maturation ponds. Two anaerobic ponds were heavily laden with water hyacinth. Maturation ponds were used for culture of both carps and tilapia while only tilapia in facultative ponds.

\section{B. Analyses}

Surface water was collected from five sites with two sub sites of one meter distance-inlet of anaerobic pond $\left(\mathrm{AP}_{i}\right)$, outlet of anaerobic pond $\left(\mathrm{AP}_{\mathrm{o}}\right)$, outlet of facultative pond
$\left(\mathrm{FP}_{\mathrm{o}}\right)$, outlet of first maturation pond $\left(\mathrm{MP}-1_{\mathrm{o}}\right)$ and outlet of fourth maturation pond (MP-4 ${ }_{0}$, regularly between April, 2007 and March, 2008 and different water quality parameters namely $\mathrm{pH}$, total alkalinity, dissolved oxygen (DO), orthophosphate-P, turbidity, total solids (TS), total dissolved solids (TDS), total suspended solids (TSS) and chemical oxygen demand (COD) of anaerobic, facultative and maturation ponds were estimated following standard methods [9]. For the estimation of Cadmium samples of water, sludge, plankton, water hyacinth and fish tissue were prepared [9] and quantified by Flame Atomic Absorption Spectrophotometer (AAS). Fecal coliform (FC) and total coliform (TC) bacteria were counted following the Multiple Tube Fermentation or Most Probable Number (MPN) Technique whereas heterotrophic bacteria (HB) were enumerated following spread plate technique [9]. The data presented were subjected to appropriate statistical tests. The variance of mean of a parameter at different sites was tested by one way ANOVA at 5\% level of significance and the comparison between any two sites or any two components were tested by multiple comparison test-Tukey at 5\% level of significance (Software Package: SPSS 10.00).

\section{RESULTS AND DISCUSSION}

\section{A. Temperature and $\mathrm{pH}$}

Water temperature ranged from 15.6 to $35{ }^{\circ} \mathrm{C}$ during the period of investigation. $\mathrm{pH}$ of surface water gradually increased from inlet (6.7-7.08) to outlet (7.6-8.3).There appeared marked seasonal variability in the $\mathrm{pH}$ values showing peak during the months of April-May and lowest during December-January. Appreciable gradual increase from the anaerobic pond to the final outlet is due to $\mathrm{CO}_{2}$ uptake by algae during photosynthesis and increase in DO. Such higher $\mathrm{pH}$ values have been reported to have a bactericidal effect [10].

\section{B. Total Alkalinity}

TABLE I: RESULTS OF DIFFERENT WATER QUALITY PARAMETERS OF DIFFERENT SITES OF TREATMENT WETLANDS DOWN THE EFFLUENT Gradient of the Wastewater Treatment System. All Parameters EXCEPT PH ARE EXPRESSED IN MG/L.

\begin{tabular}{lccccc}
\hline \hline Parameter & $\begin{array}{c}\text { Inlet of } \\
\text { Anaerobic } \\
\text { Pond }\left(\mathrm{AP}_{\mathrm{i}}\right)\end{array}$ & $\begin{array}{c}\text { Outlet of } \\
\text { Anaerobic } \\
\text { pond } \\
\left(\mathrm{AP}_{\mathrm{o}}\right)\end{array}$ & $\begin{array}{c}\text { Outlet of } \\
\text { Facultative } \\
\text { Pond (FP })\end{array}$ & $\begin{array}{c}\text { Outlet of } \\
\text { Maturation } \\
\text { Pond-1 } \\
\left(\mathrm{MP}-1_{\mathrm{o}}\right)\end{array}$ & $\begin{array}{c}\text { Outlet of } \\
\text { Maturation } \\
\text { Pond-4 } \\
\left(\mathrm{MP}-4_{\mathrm{o}}\right)\end{array}$ \\
\hline $\mathrm{pH}$ & $6.7-7.1$ & $6.9-7.3$ & $7.1-7.5$ & $7.3-7.8$ & $7.6-8.3$ \\
$\begin{array}{l}\text { Total } \\
\text { Alkalinity }\end{array}$ & $89-119$ & $113-147$ & $122-177$ & $136-188$ & $167-220$ \\
$\begin{array}{l}\text { Organic } \\
\mathrm{Carbon}\end{array}$ & $27.5-55$ & $21-48$ & $16-41$ & $11-29$ & $6-14$ \\
$\mathrm{COD}$ & $437-902$ & $386-621$ & $235-379$ & $160-191$ & $138-160$ \\
$\mathrm{DO}^{2}$ & 0 & $0-2.12$ & $7.46-15$ & $6.84-13.2$ & $6.32-11.2$ \\
$\mathrm{NH}_{4}-\mathrm{N}$ & $2.21-3.45$ & $1.8-2.97$ & $1.32-2.5$ & $1.04-2.1$ & $0.5-0.95$ \\
$\mathrm{NO}_{2}-\mathrm{N}$ & $0.02-0.219$ & $0.18-0.27$ & $0.1-0.29$ & $0.04-0.123$ & $0.013-0.055$ \\
$\mathrm{NO}_{3}-\mathrm{N}$ & $0.158-0.31$ & $0.2-0.36$ & $0.172-0.33$ & $0.158-0.25$ & $0.09-0.16$ \\
$\mathrm{OP}^{\mathrm{Fe}}$ & $0.25-0.54$ & $0.24-0.51$ & $0.2-0.47$ & $0.18-0.29$ & $0.1-0.27$ \\
\hline \hline & $4.66-4.87$ & $4.07-4.22$ & $1.08-1.33$ & $0.82-1.01$ & $0.61-0.72$ \\
\hline
\end{tabular}


The values of total alkalinity in water increased from anaerobic pond to final outlet of maturation pond during the period of study ranging from 89-119,113-147, 122-177.5, 136-188, 167-220 mg/l at $\mathrm{AP}_{i}, \mathrm{AP}_{\mathrm{o}}, \mathrm{FP}_{\mathrm{o}}, \mathrm{SP} 1_{\mathrm{o}}$ and $\mathrm{SP}_{\mathrm{o}}$, respectively (Table I). Seasonal variations in total alkalinity was clearly discernable exhibiting highest and lowest values during summer and winter, respectively.

\section{Dissolved Oxygen}

The inlet of the anaerobic pond showed absence of oxygen. DO concentrations increased gradually from facultative pond down the effluent gradient (Table I). Seasonal variability showed the higher concentrations of DO during summer and minimum during winter period. The major increase occurs in the facultative pond, due to the rapid change from anaerobic to shallow and oxygenated conditions. The higher DO level indicates better water quality which creates conducive ambience for fish in the maturation ponds [11] and for the removal of pathogenic bacteria in a process called photo-oxidation [10].

\section{Chemical Oxygen Demand}

The mean values of chemical oxygen demand ranged from 437-902, 386-621, 235-379, 160-191, and 138-160 mg/l at $\mathrm{AP}_{i}, \mathrm{AP}_{\mathrm{o}}, \mathrm{FP}_{\mathrm{o}}, \mathrm{SP}_{\mathrm{o}}$ and $\mathrm{SP} 4_{\mathrm{o}}$, respectively. There was a gradual decreasing trend of the values with $74-82 \%$ decline from inlet to outlet. The values of chemical oxygen demand reached the peak in September-October and ebb during December-January.

\section{E. Dissolved Organic Carbon}

The concentration of organic carbon in water ranged from 27.5-55, 21-48, 16-41, 11-29 and 6-14 mg/l at $\mathrm{AP}_{i}, \mathrm{AP}_{\mathrm{o}}, \mathrm{FP}_{\mathrm{o}}$, $\mathrm{SP} 1_{\mathrm{o}}$ and $\mathrm{SP} 4_{\mathrm{o}}$, respectively showing $70-78 \%$ decline during the period of study. Overall seasonal variation of organic carbon was in the order: summer $>$ monsoon > spring > winter.

\section{F. Nitrogen Species}

The average concentration of ammonium nitrogen in water ranged from $2-3.45,1.8-2.92,1.32-2.5,1.04-2.1$ and 0.5-0.95 $\mathrm{mg} / \mathrm{l}$ at $\mathrm{AP}_{i}, \mathrm{AP}_{\mathrm{o}}, \mathrm{FP}_{\mathrm{o}}, \mathrm{SP} 1_{\mathrm{o}}$ and $\mathrm{SP} 4_{\mathrm{o}}$, respectively showing an overall decline of $75-85 \%$. The concentration declined by $40-45 \%$ through the facultative ponds followed by $29-40 \%$ decline through the stocking ponds. The values reached the maximum during September-October and minimum during December-January. The mean concentrations of nitrite nitrogen observed in water ranged from 0.02-0.219, $0.18-0.27,0.1-0.29,0.04-0.123$ and $0.013-0.055 \mathrm{mg} / 1$ at $\mathrm{AP}_{i}$, $\mathrm{AP}_{\mathrm{o}}, \mathrm{FP}_{\mathrm{o}}, \mathrm{SP} 1_{\mathrm{o}}$ and $\mathrm{SP} 4_{\mathrm{o}}$, respectively during the period of investigation. The responses of nitrate-nitrogen were similar to that of nitrite-nitrogen. The mean values ranged from $0.158-0.31,0.2-0.36,0.172-0.33,0.158-0.25$ and $0.09-0.16$ $\mathrm{mg} / \mathrm{l}$ at $\mathrm{AP}_{i}, \mathrm{AP}_{\mathrm{o}}, \mathrm{FP}_{\mathrm{o}}, \mathrm{SP} 1_{\mathrm{o}}$ and $\mathrm{SP} 4_{\mathrm{o}}$, respectively. The reduction of nitrate-nitrogen from anaerobic to final outlet of stocking pond varied from 55-64\%. Maximum reduction (35\%) was registered with facultative ponds. The overall seasonal trend of variation followed the order:

summer $>$ autumn $>$ monsoon $>$ spring $>$ winter.

\section{G. Orthophosphate}

Concentrations of orthophosphate of water ranged from $0.025-0.54,0.24-0.51,0.2-0.47,0.18-0.29$ and $0.1-0.27 \mathrm{mg} / 1$ at $\mathrm{AP}_{i}, \mathrm{AP}_{\mathrm{o}}, \mathrm{FP}_{\mathrm{o}}, \mathrm{SP}_{0}$ and $\mathrm{SP}_{\mathrm{o}}$, respectively. There was large seasonal variability in the concentration of orthophosphate being maximum and minimum during the autumn and monsoon, respectively.

This is consistent with other studies showing enhanced phosphorus release rates from the sediments in anaerobic and facultative ponds and much immobilization of phosphate in maturation ponds under oxidized surface layers of the sediment [10].

\section{H. Heterotrophic Bacteria}

The counts of heterotrophic bacteria ranged from 2.4-180, $3.2-256,1.95-340.5,1.25-145$ and $0.3-72.5 \times 10^{5} / \mathrm{ml}$ at $\mathrm{AP}_{i}$, $\mathrm{AP}_{\mathrm{o}}, \mathrm{FP}_{\mathrm{o}}, \mathrm{SP}_{\mathrm{o}}$ and $\mathrm{SP} 4_{\mathrm{o}}$, respectively. There was a steady decline in the density of $\mathrm{HB}$ as the sewage effluent passed from the anaerobic pond to outlet of last stocking pond showing a decline of $87 \%$. However, the rate of decline was not uniform within a distance of $400 \mathrm{~m}$. For example, percent decline was maximum for the facultative pond and minimum for the last stocking pond showing the reduced rate of decline as the distance from the source increased and vice versa. The major removal mechanism for nitrogen in treatment wetlands is nitrification-denitrification. Oxygenation is often the limiting step for nitroigen removal. Nitrate removal in anaerobic ponds is dominant over the other ponds which were fully covered with water hyacinth and loaded with huge organic matter that may limit the oxygen diffusion to the system and created anaerobic condition in sediments. Such condition favoured the denitrification process over nitrification. Also, the supply of organic carbon raises the total heterotrophic activity, which consumes oxygen and thus indirectly favours denitrification by lowering oxygen concentrations in the sediment. A lower nitrogen removal has been observed in wetlands receiving large concentrations of ammonium nitrogen, i.e. municipal wastewater, than in those receiving nitrogen in the form of nitrate [3].

\section{Total and Fecal Coliforms}

Both groups were present in the influent at greater concentrations than the final effluent. Fecal coliform concentrations were reduced by two orders of magnitude, from $10^{6}$ to $10^{4}$. Total coliform bacteria declined along the effluent gradient, from $10^{7}$ to $10^{5} \mathrm{MPN} / 100 \mathrm{ml}$ with variation. Facultative $(87 \%)$ and maturation ponds $(75 \%)$ performed quite successfully in the removal of fecal coliform, while less efficiency was found for the total coliform bacteria (30\% for FP; $61 \%$ for MP). In a tropical climate area with high insolation and water temperature, inactivation by ultraviolet radiation and oxidation [12] are likely to play an important role in bacterial die-off.

\section{J. Cadmium in Water, Sludge and Biological Materials}

Cadmium in water was reduced by $30 \%$ from the inlet of the anaerobic pond $\left(6.67 \mathrm{~g} \mathrm{~kg}^{-1}\right)$ to the final outlet of the maturation pond (4.67 $\mathrm{g} \mathrm{kg}^{-1}$ (Fig. 1). Likewise, cadmium content of sludge also reduced from anaerobic to first maturation pond (one way ANOVA; P < 0.05). The level of $\mathrm{Cd}$ reductions was higher in the anaerobic and facultative ponds compared to the maturation ponds. This might be explained as a result of organic load dependent microbial decomposition, chelation and vertical leaching of $\mathrm{Cd}$ in the soil profile. It is stated that organic matter, clay materials, bio 
solid derived colloids possess strong binding capacity with the metals [13]. The level of cadmium in plankton as well as in all the tissues of fish was markedly higher in the facultative pond compared to the last maturation pond (one way ANOVA, $\mathrm{P}<0.05)$. Water hyacinth and freshwater bivalve, Lamellidens marginalis have been found to be good bioaccumulator of Cd from water and sediment [14].
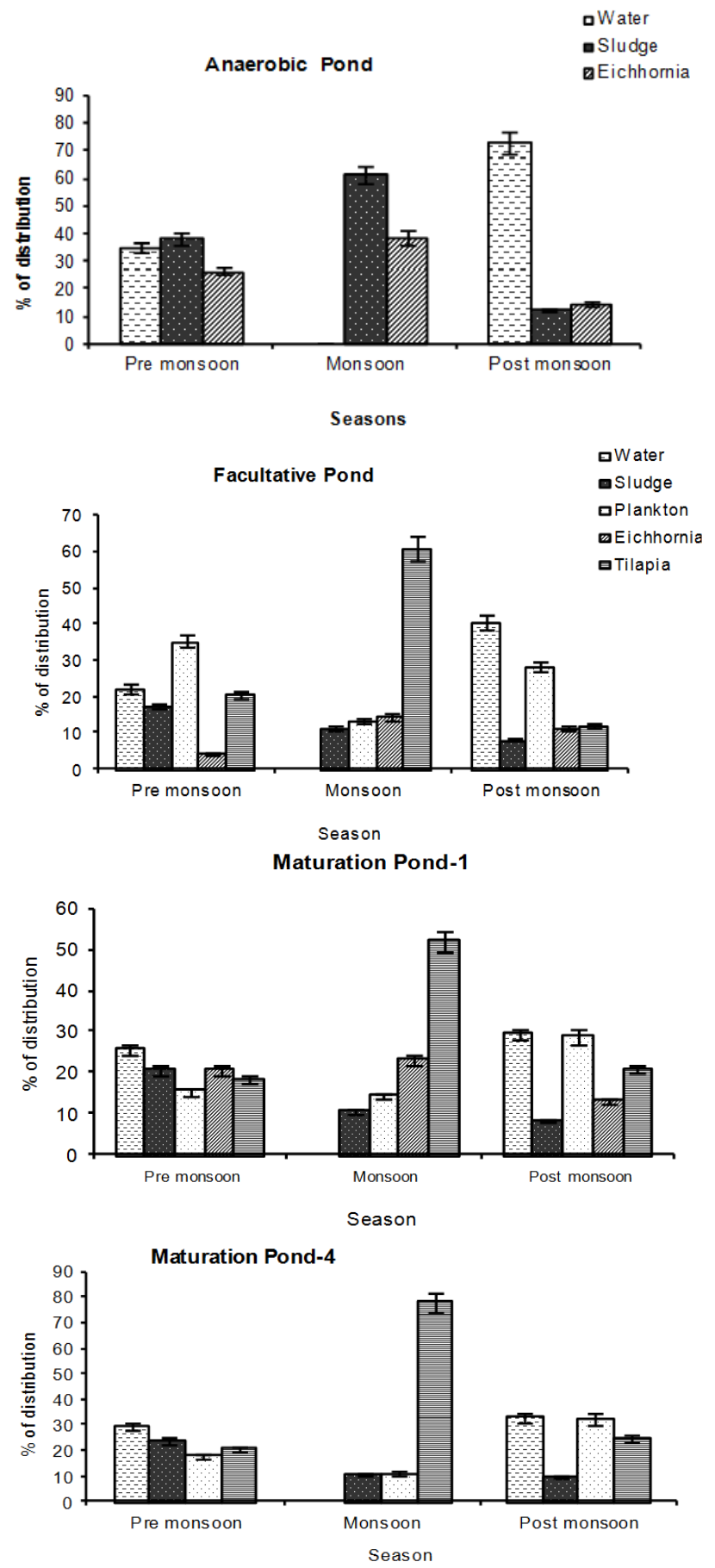

Fig. 1. Distribution (\%) of cadmium in different components of treatment ponds during pre-monsoon, monsoon and post-monsoon periods. Bar (T) represents standard error of means.

In raw sewage, most of the cadmium remained dissolved as ions because of its slight acidic nature. When it entered into anaerobic pond, dissolved $\mathrm{Cd}^{2+}$ might begin to precipitate as $\mathrm{CdS}$ and/or $\mathrm{Cd}(\mathrm{OH})_{2}$. Anoxic condition in AP favoured the formation of $\mathrm{CdS}$ and $\mathrm{Cd}(\mathrm{OH})_{2}$ while its very high organic load facilitated chelation. High sedimentation rate of organic matter in AP (1381.5-2409.6 $\mathrm{g} \mathrm{day}^{-1} \mathrm{~m}^{-3}$ ) implied that $\mathrm{Cd}$ was precipitated rapidly in AP. Presence of profuse DO $\left(7.46-17.0 \mathrm{mg} \mathrm{L}^{-1}\right)$ in facultative pond created conducive condition for the formation of $\mathrm{Fe}(\mathrm{OH})_{3}$ and its subsequent removal from FP water was attained the highest level.

The study shows that natural purification system employing treatment wetlands provides a bioregenerative wastewater reclamation strategy that can meet reuse quality standards for a variety of applications, in particular aquaculture. A three-step unified biological treatment system comprising three subsystems of two anaerobic ponds in the first step, two facultative ponds in the second step and four stocking ponds in the third step was responsible for sharp reduction of organic carbon $(70-78 \%)$, ammonium nitrogen $(75-85 \%)$, nitrite nitrogen $(67-78 \%)$, nitrate nitrogen (55-64\%) and phosphorus (50-58\%) during the course of study. Besides, cadmium load was reduced by $30 \%$ and fecal coliform load was reduced to $75-87 \%$. This clearly indicates the appreciable reclamation efficiency of the present model of treatment wetlands in which fish was the net functional output of the biological reclamation process. Depletion in nutrient contents along the sewage effluent gradient was related with the gradual decline in HB counts. Because of distinct spatial variability the bacterial counts coupled with downstream decline in organic load, the responses of these bacteria along the effluent gradient further served as functional indicators of system reclamation.

The specially designed facultative ponds were the most dynamic reclamation system of the treatment pond series due to its enhanced microbial activities and development of intense algal productivity which triggered further reclamation of effluents by providing aerobic condition; major reclamation occurred in the subsystem before being passed into the next subsystem of fish growing ponds primarily responsible for transforming organic wastes into fish biomass through the multi-channel grazing-detritus complex food chain pathways. This is of considerable significance in tropical developing countries, where production of fish protein from such low cost organic wastes is highly promising.

In order to produce maximum and safe production of fish with minimal treatment of wastewater the retention time of effluent is recommended for one day in anaerobic pond and four day in facultative pond [15]. However, in the present study, the time used for total discharge of sewage water through the series of six ponds was about 12-14 days covering a distance of $400 \mathrm{~m}$ from the site of anaerobic pond. Much longer time of retention might be considered safer to ensure maximum reclamation of wastewater in the pond system before being discharged into the open environment. A major implication of the study was that the wastewater aquaculture can be strongly recommended as a reclamation strategy for municipal sewage which would not only escape expenditure for mechanical treatment but also generate profit through production of fish biomass from sewage. The wastewater reclamation using living machines and fish biomass as the final output is of great significance in tropical developing countries because of use of energy saving biological sewage treatment system instead of extensive and energy intensive mechanical system. Hence in the present 
study treatment wetlands have been proved as an effective, low-cost, nature-based and sustainable alternative to high-cost, energy intensive conventional wastewater treatment systems. Good removal efficiencies, relatively low costs, water and nutrient reuse opportunities and other spin-off applications and ancillary benefits ensured that constructed treatment wetlands have immense potential of becoming an acceptable and appropriate ecotechnological solution to domestic wastewater treatment particularly in the developing countries.

\section{ACKNOWLEDGMENT}

This study was financed by University of Kalyani in the form of research fellowship to S. Rana.

\section{REFERENCES}

[1] S. C. Reed and D. Brown, "Subsurface flow wetlands-a performance evaluation," Wat. Environ. Res., vol. 67, no. 2, pp. 244-248, 1995.

[2] H. I. Shuval, A. Adin, B. Fattal, E. Rawitz, and P. Yekutiel, "Wastewater irrigation in developing countries: health effects and technical solutions," World Bank, Washington DC, Technical Paper No. $51,1986$.

[3] J. L. Andersson, S. K. Bastviken, and K. S. Tonderski, "Free water surface wetlands for wastewater treatment in Sweden- nitrogen and phosphorus removal," Wat. Sci. Tech. vol. 51, pp. 39-46, 2005.

[4] J. Vymazal, "Constructed wetlands for wastewater treatment," Water, vol. 2, no. 3, pp. 530-549, 2010.

[5] R. B. E. Shutes, "Artificial wetlands and water quality improvement," Environ Internat., vol. 26, pp. 441-447, 2001

[6] S. Rana, J. Jana, S. K. Bag, S. Mukherjee (Roy), J. K. Biswas, S. Ganguli (Lahiri), D. Sarker (Paria), and B. B. Jana, "Performance of constructed wetlands in the reduction of cadmium in a sewage treatment cum fish farm at Kalyani, West Bengal, India," Ecol. Eng., vol. 37, pp. 2096-2100, 2011.

[7] A. Ghermandi, D. Bixio, and C. Thoeye, "The role of free water surface constructed wetlands as polishing step in municipal wastewater reclamation and reuse," Sci.Total Environ., vol. 380, pp. 247-258, 2007.

[8] W. J. Mitsch and S. E. Jørgensen, Ecological Engineering and Ecosystem Restoration, Wiley, New York, 2004

[9] APHA (American Public Health Association), AWWA (American Water Works Association), WEF (Water Environment Federation), Standard Methods for the Examination of Water and Wastewater, 19th. ed. American Public Health Association, Washington, DC, 1995, pp. 911.

[10] H. E. Maynard, S. K. Ouki, and S. C. Williams, "Tertiary lagoons: a review of removal mechanisms and performance," Wat. Res., vol. 33, no. 1, pp. 1-13, 1999.

[11] M. B. Pescod, "Wastewater treatment and use in agriculture," FAO Irrigation and Drainage Paper 47, 1992.

[12] M. E. Kaseva, "Performance of a sub-surface flow constructed wetland in polishing pretreated wastewater-a tropical case study," Wat. Res., vol. 38, pp. 681-687, 2004.

[13] A. D. Karathanasis and D. M. C. Johnson, "Surface of transport of Cd, Cr, and Mo mediated by biosolid colloids," Sci. Total Environ., vol. 354, pp. 157-169, 2006.

[14] S. Das and B. B. Jana, "In situ cadmium reclamation by freshwater bivalve Lamellidens marginalis from an industrial pollutant-fed river canal," Chemosphere, vol. 52, pp. 161-173, 2003.

[15] D. D. Mara, P. Edwards, D. Clark, and S. W. Mills, "A rational approach to the design of wastewater-fed fish ponds," Wat. Res., vol. 27, no. 12, pp. 1797-1799, 1993.

Jayanta Kumar Biswas obtained his M.Sc. in Zoology, M.Phil. in Ecology and Ph.D. in Zoology from University of Kalyani, West Bengal, India. He is a fellow of Zoological Society (Calcutta). Presently he is working as assistant professor and coordinator in International Centre for Ecological Engineering, University of Kalyani, West Bengal, India. His areas of research include ecotechnology, ecotoxicology, environmental biotechnology, ecosystem-based management, bioregenerative reclamation of wastewater and aquatic pollution monitoring and remediation.

Sukanta Rana did his M.Sc. and Ph.D. in Zoology. He is presently a post doctoral fellow in International Centre for Ecological Engineering, University of Kalyani. His fields of research interest are waste reclamation and resource recycling and ecosystem designing. 